\title{
Türkçe Öğretmen Adaylarının Sezgisel Yolla Dil Bilgisi Öğretimine Yönelik Hazır Bulunuşlukları'
}

\author{
Ali TÜRKEL* \\ Ebru DUNDAR**
}

\begin{abstract}
Öz: Bu çalışmada 3. ve 4. sınıf Türkçe öğretmen adaylarının dil bilgisi öğretiminde sezgisel yolla öğretim yapmaya yönelik hazır bulunuşlukları saptanmaya çalışılmış, bu amaçla Dokuz Eylül Üniversitesinde 3. ve 4. sınıfta okuyan 120 Türkçe öğretmen adayıyla görüşülmüştür. Veriler nitel veri analizi yöntemiyle değerlendirilmiş, veri toplama aracı olarak araştırmacılarca geliştirilen "Yarı Yapılandırılmış Görüşme Formu” kullanılmıştır. Toplanan verilerde adayların büyük bölümünün (\%69) sezgisel yolla dil bilgisi öğretiminin kendilerine bilgi olarak öğretildiğini düşündüğü görülmüştür. Ancak adaylar uygulamaların nasıl gerçekleştirilebileceğinin örneklendirilmediğini, kuramsal bilgileri uygulamada yetersiz hissettiklerini belirtmiştir. Araştırma sonuçlarına göre adayların sezgisel yolla dil bilgisi öğretiminde yeterli kuramsal bilgiye sahip oldukları; ancak bu bilgiyi öğretebilmede kendilerini yetersiz hissettikleri söylenebilir. Sonuç olarak Türkçe öğretmenliği lisans programına uygulamayı da kapsayan sezgisel yolla dil bilgisi ögretimini içeren bir derse gereksinim olduğu görülmektedir. Türkçe öğretmenliği programlarında dinleme, konuşma, okuma, yazma becerilerinin öğretimine yönelik dersler vardır. Oysa ortaokul Türkçe ders programlarında önemli payı olan dil bilgisinin öğretimine yönelik bir ders bulunmamaktadır. Bu bir eksiklik olarak değerlendirilebilir.
\end{abstract}

Anahtar Sözcükler: Dil Bilgisi Öğretimi, Sezdirme Yöntemi, Görüş Örnekleri

\section{Turkish Preservice Teachers' Readiness for Teaching Grammar Intuitively}

\begin{abstract}
In this study, the readiness of prospective Turkish language teachers toward education in an intuitive way was examined. The sample included 120 prospective Turkish language teachers who are currently studying at 3 and 4 classes of Dokuz Eylül University. The data was collected through a semi-structured interview form was developed by the researchers. Most of the participants (69\%) believe that they have been trained for education in an intuitive way. However, candidates expressed that the practical aspects of knowledge have not been exemplified and that they feel insufficient in this regard. Based on the results of this study, Turkish preservice teachers have sufficient institutional knowledge about grammar teaching in an intuitive way but feel ill-prepared to teach the subject. Thus, Turkish language-teaching bachelor degree programs must include a course on grammar teaching using education in an intuitive way that involves practice, as well. Not having a course on teaching grammar is a great deficit, even if there are courses on teaching, listening, speaking, reading and writing skills. This can be considered a deficiency.
\end{abstract}

Keywords: Teaching Grammar, Discovery Approach, Interview Examples

${ }^{1}$ Bu çalışma 19-22 Haziran 2019 tarihlerinde düzenlenen VI. International Eurasian Educational Research Congress (EJER 2019) Ankara'da sunulan sözlü bildiriden geliştirilmiştir.

* Dokuz Eylül Üniversitesi, Eğitim Fakültesi, Türkçe Eğitimi Bölümü, İzmir, Türkiye, e posta: ali.turkel@hotmail.com,

ORCID: https://orcid.org/0000-0003-4743-8766

** Milli Eğitim Bakanlığı, Türkçe Öğretmeni, Balıkesir, Türkiye, e posta: ebru.dundar@hotmail.com, ORCID: https://orcid.org/0000-0003-1278-3092 
Ana dili eğitiminin temel amacı, bireylere anlama ve anlatma becerilerinin etkili bir biçimde kazandırılmasıdır. "Anadili öğretiminin bireylere; doğru, açık ve etkili bir iletişimi gerçekleştirebilecek dilsel becerileri kazandırma, düşünme güçlerini geliştirme, yetkinleştirme ve toplumsallaştırma süreçlerine katkıda bulunma gibi amaçları vardır." (Sever, 2000, s. 5). Türkel (2001) ana dili öğretiminin temel amacının, öğrencilerin dört temel dil becerisinin (konuşma, yazma, okuma ve dinleme) geliştirilmesi olduğunu belirtir. $\mathrm{Bu}$ becerilerin bireyin toplumsallaşmasında önemli bir etkiye sahip olduğuna dikkat çekerek üst düzey düşünme becerileri ile dil öğretimi arasında sıkı bir ilişki olduğunu vurgular. Bireylerin duygu ve düşüncelerinin aktarımını dil aracılığıyla gerçekleştirdiğini ve dilin; insanın toplumsal hayattaki yerini belirleyen ve kişiye bireysel özelliklerini kazandıran en temel yapı olduğunu belirtir. Bu temel becerilerin dil bilgisi öğretiminin temelini oluşturduğunu ve dil bilgisi öğretimine doğrudan etkisi olduğunu vurgular.

Bireyin dili doğru ve etkili kullanması için dil bilgisi öğretimi kuşkusuz büyük önem taşımaktadır. Türk Dil Kurumu (Türk Dil Kurumu [TDK], 2005) dil bilgisini "Bir dilin ses, biçim ve cümle yapısını inceleyip kurallarını tespit eden bilim dalıdır." şeklinde tanımlamaktadır. Tanımdan da anlaşılacağı üzere; dil bilgisi, dil öğretiminin temelinde yer alan ve dili inceleyen kurallar bütününü oluşturmaktadır. Dil bilgisine verilen önem bireylerin hem günlük yaşantılarını hem de akademik yaşantılarını büyük oranda etkilemektedir. Güneş (2013a) bir metni okumanın, anlamanın ve üretmenin en önemli anahtarının dil bilgisi olduğunu vurgulayarak, okuma ve yazma becerilerinin geliştirilmesinde, dilin iyi kullanılmasında ve dille ilgili sorunların çözülmesinde dil bilgisi öğretiminin anahtar kavram olduğunu belirtmektedir. Akkaya (2011) dili etkin bir şekilde kullanabilmek, duygu ve düşünceleri doğru şekilde aktarabilmek için konuşulan dilin kurallarına hakim olunması gerektiğine dikkat çeker. Ancak dil bilgisi öğretiminin bu kadar önemli olmasına karşın süreç içinde dil bilgisi dersi okullarda öğrenciler tarafından en sıkıcı ders olarak nitelendirilmektedir. Özbay (2003) bu duruma neden olarak, öğrenciyi ezberlemek zorunda bırakan ve öğrenme sürecinde öğrenciyi edilgen kılan davranışçı yaklaşımı gösterir ve bu yaklaşımın sonucu olarak öğrencilerin kendilerini ifade etmesine olanak vermediğini belirtir. Bu düşünceyi destekler şekilde Aydın (1999) bireyin etkin çabalarıyla dil öğrenimini gerçekleştirebileceğini belirterek, zihinsel gelişmeler ve sosyal ilişkilerle dilin öğrenildiğine vurgu yapar.

Günümüzde dil bilgisi öğretiminde giderek yaygınlaşan yapılandırmacı yaklaşım içerisinde yer alan sezdirme yoluyla öğretimi amacı, öğrencilerin zihinsel becerilerini geliştirerek, ezberden uzak bir dil öğrenimi gerçekleştirmektir. Jean Piaget, Vygotsky ve Bruner yapılandırıcı yaklaşımda, bireyin etkin bir biçimde rol aldığını ve zihninde yapılandırarak öğrenmeyi geçekleştirdiğini belirtir (Güneş, 2011). Sezdirme yoluyla öğretim, öğrenciye dili araştırma ve sorgulama olanağı sunmaktadır. Nguyen'e (2003) göre öğrenci bu sürece etkin bir katılım göstermekte ve zihninde kendi kendine yapılandırarak dilin kurallarını öğrenmektedir. Güneş (2013c) bu uygulama sırasında öğrencilerin gözlem yapabildiğini, kurallar oluşturduğunu, alıştırma yapma olanağı bulduğunu ve süreci gözden geçirme aşamalarını etkin bir biçimde yürütebildiğini belirtir. Bu yaklaşımla öğrenci dilin kurallarını keşfederek öğrenebilmektedir. Labédie ve Amossé (2001) öğrenmenin denetiminin öğrencide olabilmesi için, öğrencinin araştırma yapması gerektiğini ve sorgulamalarıyla sonuca kendi çabasıyla ulaşması gerektiğini belirtir. Keşfetme bu yöntemin temelini oluşturmakta ve öğrencilerin güdülenmesini sağlamaktadır.

2005 yılında geliştirilen Türkçe öğretim programı yapılandırmacı yaklaşımı temel alarak zihinsel becerilerin geliştirmesini ve öğrenciyi öğrenme sürecinde etkinleştirmeyi amaçlamaktadır (Milli Eğitim Bakanlığı [MEB], 2006). Türkçe Öğretim Programının temel hedefi, dil öğreniminde öğrenciyi merkeze alarak, kuralların ezberletilmesi yerine çeşitli etkinliklerle bu kuralların sezdirilmesi olarak tanımlanmaktadır. Davranışçı yaklaşımın aksine yapılandırmacı yaklaşım öğrenciyi ezberden ve kuraldan uzaklaştırarak, öğrencinin etkin olarak derse katılmasını esas almaktadır. Bu yaklaşım öğrencinin dili anlamasını, kullanmasını, iletişim kurmasını, dil ve zihinsel becerilerini geliştirmesini amaçlamaktadır (Güneş, 2013a). Dili doğru kullanmak, dil bilgisi öğretiminin temel amacıdır. Sever (2015) Türkçenin zenginliğini, anlatım gücünü sezip kavrayan çocukların ana dillerine karşı sevgi duymaya başlayacaklarını belirtir. Bu anlayış çerçevesinde dil bilgisi kuralları öğrenciye doğrudan verilmeden, dilin kullanım durumları etkinliklerle sezdirilmelidir.

Geleneksel dil bilgisi öğretim yöntemi öğrenciyi edilgen duruma getirerek ezberleme çabası içine 
itmektedir. Ezberleme, öğrenmenin kalıcı olmasını sağlayamamaktadır. Yapılandırmacı yaklaşım bu durumun tersine öğrencinin sürece etkin katılımını, öğrenciyi öğretim sürecinde etkin hale getirmeyi amaçlamaktadır. Aydın (1999) 2005 yılı Türkçe Öğretim Programında yer alan "benimsemeleri", "kullanmaları" ve "üretmeleri" gibi ifadelerin bu anlayışın ürünü olduğunu ve öğrencinin özne hâline getirildiğini belirtir. Bu program çerçevesinde dil bilgisi öğretimine yeni bir anlayış getirilmiştir. Özellikle dil bilgisi öğretiminde konuların diğer becerilerle ilişkilendirilmesine ve dil bilgisi öğretiminin uygulamaya dayalı olması gerektiğine dikkat çekilerek, ezberin değil örneklemenin ön planda tutulmasına ve görsel materyallerle dil bilgisi öğretiminin desteklenmesine vurgu yapılmıştır (MEB, 2006).

2006 Türkçe Dersi Öğretim Programına göre dil bilgisi öğretimi kuramsal bilgilere değil, uygulamaya dayanmalıdır (MEB, 2006). Bu amaçla dil bilgisinin öğretiminde, kuralların verilmesinin yanında, bu kuralların sözcük, cümle ve metin düzeyindeki uygulamaları amaçlanmalıdır. 2015 Türkçe Dersi Öğretim Programında dil bilgisi konularının farklı başlıklar altında verilmeden diğer öğrenme alanlarıyla beraber verildiği görülmektedir.

2019 Türkçe Dersi Öğretim Programında dil bilgisi, temel dil becerileri üzerine yapılandırılmıştır (MEB, 2019). Bu şekilde dil bilgisi kurallarının, öğrencilere temel dil becerileri ile bütünlük içinde öğretilmesi amaçlanmıştır. Programın temeli yapılandırmacı yaklaşımın üzerine kurulmuştur ve programın öğretmenlere bu konuda yol gösterebileceği öngörülmektedir.

2006 sonrası oluşturulan Türkçe öğretim programları genel olarak tüm alanlarda yapılandırmacı anlayışı benimsemiştir. Dil bilgisi derslerinde de bu yapılandırmacı anlayış çerçevesinde sezgisel yolla öğretim yapılması beklenmektedir. Çünkü ülkemizde yıllarca tanım ve kurallarla, sayılı ve sınırlı örneklerle yapılan dil bilgisi öğretimi uygulamaları, bu dersi katı ve sevimsiz bir hâle getirmiştir (Güneş, 2013b). Bu nedenle sezgisel yolla dil bilgisi öğretimine duyulan gereksinim alanyazında da sıklıkla vurgulanmaktadır (Erdem ve Çelik, 2011; Ertekinoğlu, 2003; Kırkkılıç ve Akyol, 2007; Öz, 2001; Özbay, 2006). Buna karşılık alanyazında ana dili öğretmenlerinin ve öğretmen adaylarının sezgisel yolla dil bilgisi öğretimine ilişkin hazır bulunuşluklarına ilişkin çalışma bulunmamaktadır. Bu yaklaşımı uygulayacak olanlar Türkçe öğretmenleridir. Bu öğretmenlerin ve ilerde öğretmen olacak Türkçe öğretmen adaylarının bu yaklaşıma ilişkin bilgi, beceri ve donanımları, bunlara bağlı olarak kendilerini bu yöntemle öğretim gerçekleştirmeye hazır hissedip hissetmedikleri önemlidir. Yani öğretmenlerin ve öğretmen adaylarının bilişsel, duyuşsal hazır bulunuşluklarının istenilen düzeyde olması beklenir. Devinişsel hazır bulunuşluk doğrudan bedensel beceriyle ilgilidir ve dil bilgisi öğretimi için gerekli olmayacaktır. Ancak duyuşsal ve bilişsel hazır bulunuşluk bu süreçte son derece önemlidir. Bloom'a (1995) göre olumsuz duyuşsal hazır bulunuşluğa sahip bir bireyin yeterli düzeyde öğrenebilmesi oldukça güçtür. Çünkü duyuşsal hazır bulunuşluk, bağımsız olarak başarı değişkenini \%25 oranında açıklama gücüne sahiptir (Senemoğlu, 2018). Bu oran, bilişsel hazır bulunuşluk da dâhil edildiğinde \%85'e çıkmaktadır (Sever, 1995). Bu nedenle bu araştırmada sezgisel yolla dil bilgisi öğretiminin duyuşsal ve bilişsel hazır bulunuşluk boyutları sorun olarak alınmıştır. Bu amaçla çalışmada 3. ve 4. sınıfa gelmiş Türkçe öğretmen adaylarının sezgisel yolla dil bilgisi öğretmeye yönelik duyuşsal ve bilişsel hazır bulunuşluklarını saptamak amaçlanmıştır.

\section{Yöntem}

$\mathrm{Bu}$ araştırmada Türkçe öğretmen adaylarının dil bilgisi öğretim programlarında giderek yaygınlaşan sezdirme yöntemiyle ilgili görüşlerini betimlemek amacıyla nitel bir araştırma yapılımış, çalışmada betimsel desende tarama modeli kullanılmıştır. Bu yöntem ortaya konan bir durumu aydınlatmak, belli standartlar doğrultusunda duruma ilişkin değerlendirmeler yapmak ve verilen olaylar arasındaki olası ilişkileri ortaya çıkarmak için kullanılır. Böyle araştırmalarda asıl amaç incelenen durumu etraflıca tanımlamak ve açıklamaktır (Çepni, 2018). Araştırmada bu yöntem ile Türkçe öğretmen adaylarının sezgisel yolla dil bilgisi öğretimine ilişkin bilgileri ve bu bilgilerini uygulayabilmeye yönelik hazır bulunuşlukları belirlenmeye çalışılmıştır. 


\section{Çalışma Grubu}

Çalışma grubunun belirlenmesinde amaçlı örnekleme yöntemlerinden kolay ulaşılabilir durum örneklemesi kullanılmıştır. Çalışmada Dokuz Eylül Üniversitesi Türkçe Öğretmenliği 3. sınıfta öğrenim gören 60, 4. sinıfta öğrenim gören 60 olmak üzere toplam 120 Türkçe öğretmen adayı yer almaktadır.

Nitel araştırma yöntemlerinde örneklem seçimi ve büyüklüğü konusunda belirlenmiş bir kural veya formül bulunmamaktadır (Baltacı, 2018). Bu araştırmada da örneklem büyüklüğü, belirli bir formüle veya nicel çoğunluğa göre değil; Denzin ve Lincoln'un (2008) savunduğu biçimde, verilerin doyuma ulaştığı ve döngüsel olarak tekrarlanmaya başladığı noktaya göre belirlenmiştir. Salman ve Aydın (2018) çalışmasında benzer biçimde görüşme formu öğretmen görüşlerini betimlemek için öğretmenlere uygulanmış, araştırmada 100 görüşmeci ile görüşülmüştür. Nitel çalışmalarda genellikle bu sayıya yaklaşık sayıların görüşmeci için yeterli olduğu alanyazında görülmektedir.

\section{Veri Toplama Aracı}

Araştırmanın verilerini elde etmek için yarı yapılandırılmış görüşme formu hazırlanmıştır. Görüşme formunun kapsam geçerliğini sağlamak amacıyla araştırmacılar tarafından hazırlanan sorular Türkçe eğitimi alanından üç uzmanın görüşü alınarak oluşturulmuştur. Daha sonra ön uygulamayla 15 kişilik bir gruba sorular sorulmuş, soruların açı ve anlaşlır olduğu görülmüştür. Bu süreç sonrasında araştırmacılar tarafından açı uçlu şekilde hazırlanmış üç soruluk görüşme formuna son hâli verilmiştir. Soruların anlaşılabilir ve alanyazına uygun olmasına özen gösterilmiştir. Araştırma verilerini toplamak için öğretmen adaylarına aşağıdaki sorular yöneltilmiştir:

1. Bu bölümde almış olduğunuz derslerde sezgisel yolla dil bilgisi öğretimine yönelik bir eğitim aldınız mı? Aldıysanız neleri ne kadar öğrendiğinizi, nelerin eksik kaldığını düşünüyorsunuz, açılar mısınız?

2. Sezgisel yolla dil bilgisi öğretmeye kendinizi hazır hissediyor musunuz? Neler hissettiğinizi (kendinizi hangi yönlerden yeterli, hangi yönlerden yetersiz hissettiğinize ilişkin duygu ve düşüncelerinizi) ayrıntılı bir şekilde anlatır misınız?

3. Sezgisel yolla dil bilgisi denince ne anlıyorsunuz, bir dil bilgisi konusunu sezgisel yolla öğretimini örneklendirerek açıklayabilir misiniz?

\section{Verilerin Toplanması ve Etik İlkeler}

Belirlenen üniversitede öğrenim gören öğretmen adayları ile "Yarı Yapılandırılmış Görüşme Formu"na dayalı bir biçimde görüşmeler sağlanmıştır. Çalışmaya katılmak için gönüllü olan adaylara, görüşme öncesinde çalışmanın amacına ilişkin esaslar detaylı bir biçimde açıklanmıştır. Görüşme yapılan adayların kimliği gizli tutulmuş ve adaylar "Ö" şeklinde kodlanıp numaralandırılmıştır. Her iki araştırmacı tarafından yapılan görüşmeler, ortalama 30 dakika sürmüş ve toplanan veriler yazılı bir biçimde kaydedilmiştir.

Araştırmanın yürütülme sürecinde etik ilkelere dikkat edilmiş, toplanan tüm veriler yalnızca araştırma kapsamında kullanılmıştır. Veriler üçüncü kişilerle paylaşılmamış ve katılımcılara araştırma sonuçlarının aleyhlerinde kullanılmayacağına ilişkin güvence verilmiştir.

\section{Verilerin Analizi}

Verilerin analizi için içerik analizinden yararlanılmıştır. İçerik analizinde temelde yapılan işlem, birbirine benzeyen verileri belirli kavramlar ve temalar çerçevesinde bir araya getirmek ve bunları okuyucunun anlayabileceği bir biçimde düzenleyerek yorumlamaktır (Karataş, 2015, s.71). Bu doğrultuda öğretmen adaylarının verdiği açık uçlu yanıtlarda bilişsel ve duyuşsal hazırbulunuşluğa ilişkin anahtar sözcükler (biliyorum/bilmiyorum, öğrendim/öğrenmedim, yapabilirim/yapamam vb.), verilen örnekler incelenmiş, öğretmen adaylarının kendilerini hazır görüp görmediklerine ilişkin algıları saptanmaya çalışılmıştır.

\section{Bulgular}

Türkçe öğretmenliği 3. ve 4. sınıf öğretmen adaylarının sezgisel yolla dil bilgisi öğretimine ilişkin görüşlerinin belirlenmesinin amaçlandığı bu çalışmada, bulgular alt problemlere yönelik elde edilen veriler 
1şığında sunulmuştur.

\section{Birinci Alt Probleme İlişkin Bulgular}

1) Türkçe öğretmen adaylarının lisans eğitimlerinin sezgisel yolla dil bilgisi öğretim becerilerine katkısına ilişkin görüşleri nasıldır?

\section{a) 3. Sınıf Öğretmen Adaylarının Görüşleri}

Tablo I

3. Sınıf Türkçe Öğretmen Adaylarının Sezgisel Yolla Dil Bilgisi Öğretimi Alıp Almadıklarına İlişkin Görüşleri

\begin{tabular}{lcc}
\hline & Frekans (f) & Yüzde (\%) \\
\hline Lisans eğitimi sırasında sezgisel yolla dil bilgisi öğrendiğini düşünenler & 18 & 30 \\
Lisans eğitimi sırasında sezgisel yolla dil bilgisi öğrenmediğini düşünenler & 42 & 70 \\
\hline
\end{tabular}

\section{b) 4. Sınıf Öğretmen Adaylarının Görüşleri}

Tablo II

4. Sınıf Türkçe Öğretmen Adaylarının Sezgisel Yolla Dil Bilgisi Öğretimi Alıp Almadıklarına İlişkin Görüşleri

\begin{tabular}{lcc}
\hline & Frekans (f) & Yüzde (\%) \\
\hline Lisans eğitimi sırasında sezgisel yolla dil bilgisi öğrendiğini düşünenler & 19 & 32 \\
Lisans eğitimi sırasında sezgisel yolla dil bilgisi öğrenmediğini düşünenler & 41 & 68 \\
\hline
\end{tabular}

Tablo 1 ve Tablo 2 incelendiğinde öğretmen adaylarıyla yapılan görüşmeler sonucu elde edilen verilerde, hem 3. sınıf hem de 4. sınıf öğretmen adaylarının büyük bölümü (\%69) sezgisel dil bilgisinin ne olduğunun kendilerine bilgi olarak öğretildiği ancak bunun eğitim ortamlarında nasıl uygulanacağına dönük bir eğitim almadıkları yönünde görüş bildirmiştir. Katılımcılar bu nedenle lisans eğitimlerinin, sezgisel yolla dil bilgisi öğretim becerilerine katkısının çok yetersiz olduğunu belirtmişlerdir.

Katılımcıların \%32'si ise lisansta böyle bir eğitim aldıkları ve bu eğitim sayesinde mesleğe başladıklarında dil bilgisini sezgisel yolla öğretme konusunda bilgilendiklerini belirtmiştir. Birinci alt probleme yönelik elde edilen verilerde 3. ve 4. sınıf öğretmen adaylarının görüşlerinin çok benzer olduğu görülmüştür.

Türkçe öğretmen adaylarının lisans eğitiminin sezgisel yolla dil bilgisi öğretimi becerisine katkısına ilişkin görüş örnekleri Tablo 3'te sunulmuştur.

Tablo III

Türkçe Öğretmen Adaylarının Lisans Eğitimlerinin Sezgisel Yolla Dil Bilgisi Öğretim Becerilerine Katkısına İlişkin Görüşleri

\begin{tabular}{|c|c|c|}
\hline Tanım & 3. sınıf öğretmen adayları örnek görüşleri & 4. sınıf öğretmen adayları örnek görüşleri \\
\hline $\begin{array}{l}\text { Türkçe öğretmen } \\
\text { adaylarının lisans } \\
\text { eğitimlerinin sezgisel } \\
\text { yolla dil bilgisi öğretim } \\
\text { becerilerine katkısına } \\
\text { ilişkin görüşleri }\end{array}$ & $\begin{array}{l}\text { Ö15: Sezgisel yolla öğretim yapmamız her } \\
\text { derste söylendi ama nasıl uygulayacağımız } \\
\text { konusunda bilgilenmedik. } \\
\text { Ö19: Bir eğitim aldık ama yeterli değildi. } \\
\text { Uygulamada eksiklerimizin olduğunu } \\
\text { düşünüyorum. } \\
\text { Ö31: Dil bilgisi öğretiminin sezgisel yolla } \\
\text { yapılacağı cümlelerini çok kez duyduk ama } \\
\text { buna yönelik bir eğitim aldığımızı } \\
\text { düşünmüyorum. } \\
\text { Ö39: Özel öğretim yöntemleri dersinde sezgisel } \\
\text { yolla dil bilgisinin öğretilmesine yönelik } \\
\text { bilgilendik. Dil bilgisinin öğrenciye ezber } \\
\text { yoluyla değil metin üzerinden bağlamla } \\
\text { verilmesi daha anlamlı ve kalıcı öğrenmeler } \\
\text { sağlar. }\end{array}$ & $\begin{array}{l}\text { Ö1: Aldığımız dersler sezgisel yolla dil bilgisi } \\
\text { ögretiminin önemine vurgu yapar nitelikte olsa } \\
\text { da sezgisel yolla dil bilgisi ögretimi adında } \\
\text { veya bunu temele alan bir dersimiz olmadı. } \\
\text { Ö12: Dil bilgisini kurallar şeklinde değil de } \\
\text { sezdirilerek öğretilmesi gerektiği bilgisini aldık } \\
\text { fakat nasıl sezdireceğimiz konusunda bir } \\
\text { bilgim yok. } \\
\text { Ö9: Derslerde bahsi geçse de havada kalan bir } \\
\text { konu olduğunu düşünüyorum. Sezdirmemiz } \\
\text { gerektiği söylendi ama bunu nasıl yapmam } \\
\text { gerektiğini bilmiyorum. } \\
\text { Ö8: Sezgisel yolla dil bilgisi öğretimine yönelik } \\
\text { eğitim aldım. Öğrencilere dil bilgisini kurallar } \\
\text { ve kavramlar yoluyla değil dilin günlük } \\
\text { kullanımındaki haliyle sezdirilerek öğretilmesi } \\
\text { gerektiğini öğrendim. }\end{array}$ \\
\hline
\end{tabular}

\section{İkinci Alt Probleme İlişkin Bulgular}

2) Türkçe öğretmen adaylarının sezgisel yolla dil bilgisi öğretmeye kendilerini hazır hissedip hissetmediklerine ilişkin görüşleri nasıldır? 


\section{a) 3. Sınıf Öğretmen Adaylarının Görüsşleri}

\section{Tablo IV}

3. Sımı Türkçe Öğretmen Adaylarının Sezgisel Yolla Dil Bilgisi Öğretimine İlişkin Öz Yeterlik Algıları

\begin{tabular}{lcc}
\hline & Frekans (f) & Yüzde (\%) \\
\hline Sezgisel yolla dil bilgisi öğretimi için kendini hazır hissedenler & 11 & 19 \\
Sezgisel yolla dil bilgisi öğretimi için kendini hazır hissetmeyenler & 49 & 81 \\
\hline
\end{tabular}

\section{b) 4. Sınıf Öğretmen Adaylarının Görüşleri}

Tablo V

4. Sını Türkçe Öğretmen Adaylarının Sezgisel Yolla Dil Bilgisi Öğretimine İlişkin Öz Yeterlik Algıları

\begin{tabular}{lcc}
\hline & Frekans (f) & Yüzde (\%) \\
\hline Sezgisel yolla dil bilgisi öğretimi için kendini hazır hissedenler & 12 & 20 \\
Sezgisel yolla dil bilgisi öğretimi için kendini hazır hissetmeyenler & 48 & 80 \\
\hline
\end{tabular}

Tablo 4 ve Tablo 5 incelendiğinde 3. ve 4. sınıf Türkçe öğretmen adaylarının sezgisel yolla dil bilgisi öğretimine ilişkin öz yeterlik algılarının neredeyse aynı olduğu görülmektedir. Katılımcıların büyük oranı, bu yönde bir eğitim almadıklarından kendilerini sezgisel yolla dil bilgisi öğretebilme konusunda hazır görmemektedir. Türkçe öğretmen adaylarının sezgisel yolla dil bilgisi öğretmeye kendilerini hazır hissedip hissetmediklerine ilişkin görüş örnekleri Tablo 6'da sunulmuştur.

Tablo VI

Türkçe Öğretmen Adaylarımın Sezgisel Yolla Dil Bilgisi Öğretmeye Kendilerini Hazır Hissedip Hissetmediklerine Illişkin Görüşleri

\begin{tabular}{|c|c|c|}
\hline Tanım & 3. sınıf öğretmen adayları örnek görüşleri & 4. sınıf öğretmen adayları örnek görüşleri \\
\hline $\begin{array}{l}\text { Türkçe öğretmen } \\
\text { adaylarının sezgisel } \\
\text { yolla dil bilgisi } \\
\text { öğretmeye kendilerini } \\
\text { hazır hissedip } \\
\text { hissetmediklerine } \\
\text { ilişkin görüşleri }\end{array}$ & 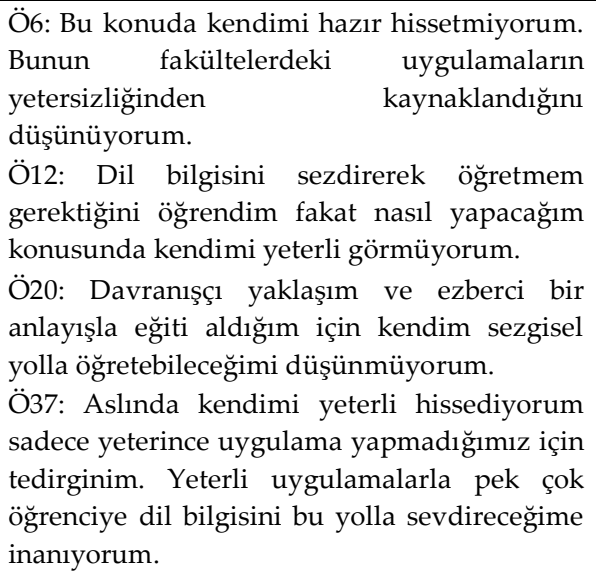 & $\begin{array}{l}\text { Ö11: Kendimi hazır hissediyorum, sezgisel } \\
\text { yolla iyi bir eğitim vereceğimi düşünüyorum. } \\
\text { Ö31: Sezgisel yolla dil bilgisi öğretmeye } \\
\text { kendimi hazır hissetmiyorum. Uygulamaya } \\
\text { yönelik eğitimlerin fakültelerde ihmal } \\
\text { edildiğini düşünüyorum. } \\
\text { Ö40: Dil bilgisinin sezgisel olarak anlatımına } \\
\text { ilişkin özel bir eğitim almadığım için } \\
\text { hazırlıksızım. } \\
\text { Ö49: Kendimi bu konuda hazır hissediyorum. } \\
\text { Ezberci eğitime karşı yapılandırmacı eğitimi } \\
\text { temel alıyorum. } \\
\text { Ö46: Kendimi hazır hissetmiyorum. Biz teorik } \\
\text { olarak bazı şeyleri öğrendik ama bize bunun } \\
\text { nasıl uygulanacağı gösterilmedi. }\end{array}$ \\
\hline
\end{tabular}

\section{Üçüncü Alt Probleme İlişkin Bulgular}

3) Türkçe öğretmen adaylarının sezgisel yolla dil bilgisi öğretimi tanımları ve yönteme ilişkin örneklemeleri nasildır?

Tablo VII

3. Sınıf Türkçe Öğretmen Adaylarının Sezgisel Yolla Dil Bilgisi Öğretimi Tanımları

\begin{tabular}{|c|c|c|c|}
\hline \multirow{2}{*}{ Tanım } & \multirow{2}{*}{ Kodlar } & \multicolumn{2}{|c|}{ Tekrarlanma Sayısı } \\
\hline & & $\mathbf{f}$ & $\%$ \\
\hline \multirow{4}{*}{$\begin{array}{l}\text { Sezgisel yolla dil bilgisi } \\
\text { öğretimi denilince ne } \\
\text { anlıyorsunuz? }\end{array}$} & Ezber dişı öğrenmeleri anlıyorum. & 20 & 33 \\
\hline & Buluş yoluyla öğrenmeyi anlıyorum. & 16 & 27 \\
\hline & Öğrenci merkezli öğrenmeyi anlıyorum. & 14 & 23 \\
\hline & Yapılandırmacılığı anlıyorum. & 10 & 17 \\
\hline
\end{tabular}

Tablo VIII

4. Sını Türkçe Öğretmen Adaylarının Sezgisel Yolla Dil Bilgisi Öğretimi Tanımları

\begin{tabular}{llcc}
\hline \multirow{2}{*}{ Tanım } & Kodlar & \multicolumn{2}{c}{ Tekrarlanma Sayısı } \\
\cline { 3 - 4 } & & \% & $\mathbf{f}$ \\
\hline Sezgisel yolla dil bilgisi & Ezber dişı öğrenmeleri anliyorum. & 14 & 23 \\
\hline
\end{tabular}




\begin{tabular}{llcc}
\hline \multirow{2}{*}{$\begin{array}{l}\text { öğretimi denilince ne } \\
\text { anlıyorsunuz? }\end{array}$} & Buluş yoluyla öğrenmeyi anlıyorum. & 27 & 45 \\
\cline { 2 - 4 } & Öğrenci merkezli öğrenmeyi anlıyorum. & 4 & 7 \\
\cline { 2 - 5 } & Yapılandırmacılığı anlıyorum. & 15 & 25 \\
\hline
\end{tabular}

Öğretmen adaylarının üçüncü alt probleme verdikleri yanıtlar, araştırmacılar tarafından ifadelerin benzerliğine göre: “Buluş yoluyla öğrenmeyi anlıyorum, yapılandırmacılığı anlıyorum, ezber dışı öğrenmeleri anlıyorum, öğrenci merkezli öğrenmeyi anlıyorum." şeklinde gruplandırılmıştır.

Tablo 7 incelendiğinde 3 . sınıf öğretmen adaylarının sezgisel yolla dil bilgisi öğretimi denilince anladıkları çoğunlukla (\%33) ezber dışı öğrenmelerdir. Bunu sırasıyla buluş yoluyla öğrenme (\%27), öğrenci merkezli öğrenme (\%23) ve yapılandırmacılık (\%17) takip etmektedir.

Tablo 8'de 4. sınıf öğretmen adaylarının sezgisel yolla dil bilgisi öğretimi denilince anladıkları ise çoğunlukla (\%45) buluş yoluyla öğrenmedir. Ardından sırasıyla yapılandırmacılık (\%15), ezber dışı öğrenmeler (\%14) ve öğrenci merkezli öğrenme de (\%4) katılımcıların sezgisel yolla dil bilgisine ilişkin betimlemeleridir. Araştırmada elde edilen verilerden hareketle sezgisel yolla öğretimin ne olduğu konusunda her iki seviyedeki (3. ve 4. sınıf) öğretmen adaylarının kuramsal olarak doğru bilgilere sahip olduğu görülmüştür.

Görüşme yapılan öğretmen adaylarının yönteme ilişkin örneklemeleri ise oldukça sınırlıdır. Hem 3. hem de 4. sınıf Türkçe öğretmen adaylarının çoğunlukla örnek verme konusunda zorlandığı görülmüştür ve verilen örnekler de genellikle benzerdir. Bunlar büyük oranda herhangi bir sözcük grubunun metnin içinden çıkarılarak işlevini hissettirmeye yönelik örneklemelerdir.

Türkçe öğretmen adaylarının sezgisel yolla dil bilgisi öğretimi yöntemine ilişkin görüş örnekleri Tablo 9'da sunulmuştur.

\section{Tablo IX}

Türkçe Öğretmen Adaylarının Sezgisel Yolla Dil Bilgisi Öğretimi Yöntemine İlişkin Örneklemeleri

\begin{tabular}{|c|c|c|}
\hline Tanım & 3. sınıf öğretmen adayları örnek görüşleri & 4. sınıf öğretmen adayları örnek görüşleri \\
\hline $\begin{array}{l}\text { Türkçe öğretmen } \\
\text { adaylarının sezgisel } \\
\text { yolla dil bilgisi öğretimi } \\
\text { yöntemine ilişkin } \\
\text { örneklemeleri }\end{array}$ & $\begin{array}{l}\text { Ö23: Örneğin ek anlatırken kelimeden eki } \\
\text { çıarıp anlamın ne yönde değiştiğini, ekin nasıl } \\
\text { bir işlevinin olduğunu hissettirmek. } \\
\text { Ö33: Örneğin sıfat türünü ismi çeşitli } \\
\text { yönlerden niteleyen addır demek yerine sıfatın } \\
\text { işlevi üzerinden ne olduğu sezdirilmeye } \\
\text { çalışılır. } \\
\text { Ö47: Örneğin zarf konusunu öğretirken zarfın } \\
\text { tanımını vermek yerine metinde geçen } \\
\text { zarfların işlevlerini öğrencinin kendisinin } \\
\text { bulmasını sağlamalıyız. } \\
\text { Ö53: Burada konuyu direkt öğretmen } \\
\text { aktarmaz. Örneğin zamir konusunu işlerken } \\
\text { metinden içinde zamir geçen cümleler seçilir. } \\
\text { Öğretmen, öğrencilere zamiri gösterir ve } \\
\text { kelimenin cümlede nasıl bir işlevi olduğunu } \\
\text { sorar. }\end{array}$ & $\begin{array}{l}\text { Ö55: Örneğin sıfat anlatırken «kırmızı araba» } \\
\text { tamlamasındaki sıfatın işlevini sorularla } \\
\text { öğrencinin bulmasını sağlamak. } \\
\text { Ö26: Tanımlama yapmadan metin içinde } \\
\text { çocuğun sıfatı bulmasını ve işlevini } \\
\text { kavramasını sağlarım. } \\
\text { Ö25: Örneğin bir kelimenin yapım eki almadan } \\
\text { önce ve aldıktan sonraki anlamları } \\
\text { kıyaslanarak öğrenciye ekin işlevi } \\
\text { sezdirilebilir. } \\
\text { Ö18: Noktalama işaretlerini doğrudan } \\
\text { anlatmak yerine metin üzerinden boşlukları } \\
\text { doldurarak bunların işlevi kavratılabilir. } \\
\text { Ö51: Tek bildiğim örnek, noktalama işaretsiz } \\
\text { metin verip noktalamanın önemini } \\
\text { kavratmaktır. }\end{array}$ \\
\hline
\end{tabular}

\section{Sonuç, Tartışma ve Öneriler}

\section{Sonuç}

Türkçe Öğretmenliği 3 ve 4. sınıf öğretmen adaylarının dil bilgisi öğretiminin sezgisel yolla öğretimine yönelik donanımlarına ilişkin görüşlerinin belirlenmeye çalışıldığı bu çalışmada görüşme formlarından elde edilen verilerden hareketle aşağıdaki sonuçlara ulaşılmıştır:

1. Öğretmen adaylarının lisans eğitimlerinin sezgisel yolla dil bilgisi öğretim becerilerine katkısı oldukça düşüktür. Katılımcılar çoğunlukla bu yönde bir eğitim almadıkları yönünde görüş belirtmiştir. 
2. Türkçe öğretmen adaylarının sezgisel yolla dil bilgisi öğretmeye kendilerini hazır hissetmediği görülmüştür. Bu durum onların dil bilgisi öğretimine yönelik tutumlarını etkileyecektir. Öğretmen adaylarının bu konudaki öz yeterliklerinin artması, lisansta bu yönde bir eğitim almaları ve bunu deneyimlemeleri ile mümkün olabilir.

3. Türkçe öğretmen adaylarının sezgisel yolla dil bilgisi öğretimi tanımları ve yönteme ilişkin örneklemeleri incelendiğinde katılımcıların doğru tanımlamalar yaptıkları ancak örnekleme yapma konusunda sorun yaşadığı görülmüştür. Yani sezgisel yolla öğretimin ne olduğunu kuramsal olarak bilinmekte fakat bunun uygulamaya yönelik kısmında yetersiz kalınmaktadır.

\section{Tartışma}

Bu çalışmada Türkçe Öğretmenliği 3. ve 4. sınıf öğretmen adaylarının dil bilgisi öğretiminin sezgisel yolla öğretimine yönelik hazır bulunuşluklarına ilişkin görüşleri belirlenmeye çalışılmıştır. Katılımcılara uygulanan görüşme formlarından elde edilen verilere göre Türkçe öğretmen adaylarının çoğunun sezgisel yolla dil bilgisine ilişkin yeterli kuramsal bilgiye sahip olduklarını (katılımcıların tümü), ancak bunu uygulamaya yansıtacak beceriye sahip olmadıklarını düşündükleri (\%69) görülmüştür. Sezgisel yolla dil bilgisi öğretimini öğrendiği düşünenlerin oranı da az değildir (\%32). Bu, şöyle yorumlanabilir: Öğretmen adayları sezgisel yolla dil bilgisi öğretimine ilişkin doyurucu kuramsal bilgiyi lisans eğitimlerinde almış, uygulamalar da yapmış olabilirler; ancak uygulamalar yetersiz kalmış olabilir. Yapılan bu çalışma ile dil bilgisi lisans eğitiminin, uygulamaya yönelik boyutunun artırılmasına gereksinim olduğu görünmektedir. İşcan (2007) da dil bilgisi öğretimine ilişkin yaptı̆̆ı araştırmada, dil bilgisinin işlevsel yönünü ön plana çıkaran metotların kullanılmasının dil bilgisi öğretiminde sağlıklı ve kalıcı sonuçları beraberinde getireceğini belirtmiştir.

Yine de ortada bir sorun olduğu, adayların öğretmenlik mesleğine başladıklarında sezgisel yolla dil bilgisi öğretimi yapma konusunda güçlük yaşayacağı düşünülebilir. Nitekim Ayrancı (2017) tarafından yapılan benzer bir çalışmada sezdirme yöntemine ilişkin Türkçe öğretmenleriyle görüşülmüş ve dil bilgisi öğretiminin bu yöntemle yapılması gerektiğine katılan ve katılmayan öğretmenlerin sayısı neredeyse eşit çıkmıştır. Ayrancı'ya göre (2017) uygulamanın içerisinde olan öğretmenlerin yıllardır süregelen sezgisel dil bilgisi öğretimine bu şekilde görüş bildirmesi oldukça düşündürücüdür. Aynı şekilde Salman ve Aydın (2018) tarafından yapılan, yapılandırmacı yaklaşıma göre dilbilgisi öğretimine ilişkin öğretmen görüşlerinin toplandığı benzer bir araştırmada da katılımcıların sadece \%50'si dil bilgisi öğretim sürecini yapılandırmacı yaklaşıma göre sürdürürken, \%39'u bu süreçte karma uygulamaları kullanmaktadır. Öğretmenlerin \%11'inin ise yıllardır uygulamada olan programa rağmen geleneksel yöntemlerle dil bilgisi öğretimi yapmayı sürdürmesi dikkat çekicidir.

Yapılan bu çalışmada öğretmen adaylarının herhangi bir dil bilgisi konusunu sezgisel yolla öğretimini örneklendirme konusunda çok yetersiz kalması benzer şekilde şaşırtıcı bir sonuçtur. Adayların örneklendirmede çoğunlukla, sezgisel yolla öğretimin anlatıldığı kitaplarda geçen boşluklara uygun noktalama işaretlerinin veya sözcük türünün yerleştirilmesi gibi basmakalıp örneklerden öteye gidemediği görülmüştür. Yine bu durumun öğretmen adaylarının sezgisel yolla dil bilgisi ile uygulamalar yapma olanağından yoksun kaldıklarının göstergesi olduğu söylenebilir.

Uygulama, öğrenilmiş bilgilerin yeni ve benzer durumda kullanılmasıdır. Kuralların ve genel fikirlerin uygulanmasını içerir. Bu basamak, öğrenilen bilgilerin ne derece transfer edilebildiği ve yeni problemlerin çözümünde ne oranda kullanabildiği ile ilgilidir. Bu sebeple uygulama basamağı, bilgi ve kavrama düzeyindeki davranışları da kapsayan çok yönlü bir süreçtir (Ergin, 2005). Dil bilgisi öğretiminin uygulama ağırlıklı olması ve bu süreçte çağdaş eğitim yaklaşımlarının uygulanması gerektiği uzun yıllardır araştırmacılarca vurgulanmaktadır. Aydın (1999) da ortaokullarda dil bilgisi öğretimi üzerine öğretmen görüşlerini topladığı çalışmasında benzer durumlara vurgu yapmıştır. Bu sebeple öğretim sürecinin uygulamaya dönük olmasının öğretimde kaliteyi ve kalıcılığı arttıracağı söylenebilir. Güneş (2013b) dil bilgisi öğretiminde bireylerin araştırma ve gözlem yapma, sorgulama ve sorun çözme gibi süreçleri kullanacakları uygulamalar ile öğrenme ve öğretmenin gerçekleşeceğini savunur. Uygulamaların yetersiz kaldığı ve yalnızca 
kuramsal bilgilerin sunulduğu eğitim ortamlarında öğrenme eylemi amacına tam olarak ulaşamamaktadır.

Bireyin herhangi bir konuyla ilgili ön bilgi ve tutumunu içeren hazır bulunuşluğun (Yenilmez ve Kakmacı, 2008) öğrenme sürecinde ne denli önemli olduğu alanyazında yapılmış birçok çalışmada üzerinde önemle durulan bir konudur (Başar, 2001; Bloom, 1995; Harman ve Çeliker, 2012; Senemoğlu, 2018; Yenilmez ve Kakmacl, 2008). Bu araştırmada elde edilen verilerde öğretmen adaylarının sezgisel yolla dil bilgisi öğretimi konusunda hazır bulunuşluklarının yetersiz olduğu görülmüştür. Katılımcılar bu durumu lisans eğitimleri sırasında böyle bir eğitimin almamalarına bağlamaktadır. Ayrancı (2017) tarafından yapılan araştırma sonucunda elde edilen veriler, aynı durumun uygulamadaki öğretmenler için de geçerli olabileceğini düşündürmektedir. Bu durum lisans eğitiminde sezgisel yolla dil bilgisi öğretiminin ne derece önemli olduğunu açıkça göstermektedir.

\section{Öneriler}

Araştırmaya katılan öğretmen adayları çoğunlukla lisansta sezdirme yönteminin öğretimine ilişkin bir eğitim almadıklarını belirtmiş ve bu konuda kendilerini yetersiz hissettiklerini söylemiştir. Bu sebeple Türkçe öğretmenliği programı lisans derslerine uygulamaya yönelik sezgisel yolla dil bilgisi öğretimi eğitiminin dâhil edilmesi önerilebilir. Ayrıca alanyazın incelendiğinde sezgisel yolla dil bilgisi öğretimine yönelik yeterli çalışma olmadığı görülmüştür. Bu konudaki çalışmalar ve kaynakların artırılması önerilebilir.

Öğretmen adaylarının sezgisel yolla öğretime ilişkin uygulama örneklerine bakıldığında katılımcıların nerdeyse tamamının bu konuda hazır olmadığı görülmüştür. Aynı durum, uygulamadaki öğretmenler için de geçerli olabilmektedir. Bu nedenle öğretmenlere bu yönde seminerler verilebilir.

\section{Yazar(lar)ın Beyanı}

Araştırmacıların katkı oranı beyanı: Birinci yazar makalenin veri toplama, veri analizi, raporlaştırma ve diğer aşamalarında sorumlu yazardır. 2. yazar verilerin toplanması ve analizinde görev almıştır. Yazarlar, bu çalışmada 1. araştırmacının katkı oranının $\% 60$, 2. araştırmacının $\% 40$ olduğunu beyan ederler.

Çatışma beyanı: Makalenin yazarları bu çalışma ile ilgili taraf olabilecek herhangi bir kişi ya da finansal ilişkileri bulunmadığını dolayısıyla herhangi bir çıkar çatışmasını olmadığııı beyan ederler.

Destek ve teşekkür: Çalışmada herhangi bir kurum ya da kuruluştan destek alınmamıştır.

\section{Kaynaklar}

Akkaya, A. (2011). Karikatürlerle dil bilgisi öğretimi. Selçuk Üniversitesi: Konya.

Aydın, Ö. (1999). Orta okullarda dil bilgisi öğretimi üzerine öğretmen görüşleri. Dil Dergisi, 81(1), 23-29.

Ayrancı, B. B. (2017). Sezdirme yöntemi ile dil bilgisi öğretimi üzerine Türkçe öğretmenlerinin görüşlerinin incelenmesi. International Journal of Languages' Education and Teaching, 5(4), 145-164.

Baltacı, A. (2018). Nitel araştırmalarda örnekleme yöntemleri ve örnek hacmi sorunsalı üzerine kavramsal bir inceleme. Bitlis Eren Üniversitesi Sosyal Bilimler Enstitüsü Dergisi, 7(1), 231-274.

Başar, E. (2001). Genel öğretim yöntemleri. Samsun: Kardeşler Ofset ve Matbaa.

Bloom, B. (1995). İnsanın nitelikleri ve okulda öğrenme. (Çev. Durmuş Ali Özçelik). Ankara: Milli Eğitim Basımevi.

Çepni, S. (2018). Araştırma ve proje çalışmalarına giriş. Trabzon: Salih Çepni Yayınları.

Denzin, N. K. ve Lincoln, Y. S. (2008). The landscape of qualitative research. New York: Sage.

Erdem, İ. ve Çelik, M. (2011). Dil bilgisi öğretimi yöntemi üzerine değerlendirmeler. Turkish Studies, 6(1), 1057-1069.

Ergin, H. (2005). Okul öncesi dönemde Bloom'un bilişsel alan sınıflandırmasını kullanarak çocukların düşünme becerilerinin geliştirilmesi. Hasan Ali Yücel Ĕ̆gitim Fakültesi Dergisi, 1(1), 93-105. 
Türkçe Öğretmen Adaylarının Sezgisel Yolla...

Ertekinoğlu, S. (2003). Türkçe derslerinde dil bilgisi öğretimi üzerine öğretmen görüşlerinin değerlendirilmesi, (Yayımlanmamış yüksek lisans tezi). Marmara Üniversitesi, İstanbul.

Güneş, F. (2011). Dil öğretim yaklaşımları ve Türkçe öğretimindeki uygulamalar. Mustafa Kemal Üniversitesi Sosyal Bilimler Enstitüsü Dergisi, 8(15), 123-148.

Güneş, F. (2013a). Türkçe öğretimi yaklaşımlar ve modeller. Ankara: Pegem Akademi.

Güneş, F. (2013b). Dil bilgisi öğretiminde yeni yaklaşımlar. Dil ve Edebiyat Eğitimi Eğitimi Dergisi, 2(7), 71-92.

Güneş, F. (2013c). Yapılandırıcı yaklaşımla dil bilgisi öğretimi. Journal of Theory and Practice in Education, 9(3), 171-187.

Harman, G. ve Çeliker, D. (2012). Eğitimde hazır bulunuşluğun önemi üzerine bir derlem çalışması. Eğitim ve Öğretim Araştırmaları Dergisi, 1(3), 147-156.

İşcan, A. (2007). İşlevsel dil bilgisinin Türkçe öğretimindeki yeri. Atatürk Üniversitesi Sosyal Bilimler Enstitüsü Dergisi, 9(1), 253-258.

Karataş, Z. (2015). Sosyal bilimlerde nitel araştırma yöntemleri. Manevi Temelli Sosyal Hizmet Araştırmaları Dergisi, 1(1), 63-80.

Kırkkılıç, A. ve Akyol, H. (2007). İköğretimde Türkçe öğretimi. Ankara: PegemA yayıncılık.

Labédie, G. ve Amossé, G. (2001). Constructivisme ou socio-constructivisme. Pädagogisches Institut der Deutschen Sprachgruppe: Bozen DDEC de Nantes.

Milli Eğitim Bakanlığı (2006). Türkçe öğretim programı. Ankara: Talim ve Terbiye Kurulu Başkanlığı.

Milli Eğitim Bakanlığı (2019). Türkçe öğretim programı. Ankara: Talim ve Terbiye Kurulu Başkanlığı.

Nguyen, Q. T. (2003). Enseigner la grammaire aujourd'hui. Formation et autoformation des enseignants de Français: Université Nationale de Hanoi.

Öz, M. F. (2001). Uygulamalı Türkçe öğretimi. Ankara: Anı Yayıncılık.

Özbay, M. (2003). Türkçe öğretiminde hedef-araç ilişkisinin ders kitabı örneğinde değerlendirilmesi. Türklük Bilimi Araştırmaları Dergisi, 13(1), 59-70.

Özbay, M. (2006). Özel öğretim yöntemleri II. Ankara: Öncü Kitap.

Salman, B. ve Aydın, İ. S. (2018). Yapılandırmacı yaklaşıma göre dil bilgisi öğretimine yönelik öğretmen görüşleri. Turkish Studies, 13(27), 1265-1284.

Sağır, M. (2002). İlköğetim okullarında Türkçe dil bilgisi öğretimi. Ankara: Nobel Yayın Dağıtım.

Senemoğlu, N. (2018). Gelişim öğrenme ve öğretim kuramdan uygulamaya. Ankara: Anı Yayıncılık.

Sever, S. (1995). Türkçe öğretiminde tam öğrenme. İstanbul: Ya-Pa Yayıncılık.

Sever, S. (2000). Türkçe öğretimi ve tam öğrenme. Ankara: Anı Yayıncılık.

Türk Dil Kurumu (2005). Türkçe sözlük. Ankara: TDK Yayınları.

Türkel, A. (2001). Yükseköğretim Türk dili derslerinin yaratıcı ve bilimsel düşünmeyi geliştirme düzeyine ilişkin bir değerlendirme. Dil Dergisi, 10(2), 25-47.

Yenilmez, K. ve Kakmacı, Ö. (2008). İlköğretim yedinci sınıf öğrencilerinin matematikteki hazır bulunuşluk düzeyi. Kastamonu Ĕ̆itim Dergisi, 16(2), 529-542. 


\section{EXTENDED ABSTRACT}

\section{Introduction}

Grammar is a discipline that identifies rules by investigating the phonology, style, and sentential structures of a language (TDK, 2005). The importance given to grammar greatly affects individuals' daily and academic lives. Teaching grammar is key for students to develop reading and writing skills, use the language well, and solve language-related problems (Güneş, 2013b). Speaking and writing accurately is possible only if one has command over grammar, which can be ensured by teaching grammar (Sağır, 2002).

In our country, grammar teaching is fulfilled through various activities, methods, and techniques in firstlanguage lessons. In accordance with the 2006 Turkish Curriculum, a constructivist approach was adopted in grammar teaching across the country. In contrast to behavioristic patterns, the constructivist approach, by means of distancing students from memorization and rules, aims to engage them in classes and enable them to understand and use the language, communicate, and develop their linguistic and cognitive skills (Güneş, 2013c). It is anticipated that constructivist Turkish teaching is likely to harness a grammar teaching approach that emphasizes teaching based on intuition. Teaching through intuition has been popularized in the context of grammar teaching in recent years. It is a product of the constructivist model that aims at creating a languageteaching environment that is far from memorization, by improving students' cognitive skills. In other words, intuition-based teaching provides students with the opportunity to investigate and question the language; this has been frequently emphasized in the related literature, as well. However, the number of studies on grammar teaching through intuitive means in the field seems inadequate. In addition, it is crucial to know whether preservice teachers who are expected to teach intuitively at schools feel confident about this and to identify their opinions about their readiness and knowledge levels in teaching through intuitive means. Therefore, this study investigated the knowledge and readiness levels of 3rd and 4th grade preservice Turkish teachers with regard to teaching grammar through intuition, and the following questions were administered to preservice teachers through interview forms:

1) Have you taken any lessons in your department on grammar teaching based on intuition? If yes, can you explain what you have learned and what was missing in the lesson?

2) Do you feel ready to teach grammar through intuition? Can you describe what you feel (your opinions about personal strengths and weaknesses) in moderate detail?

3) What do you understand by grammar teaching through intuition? Can you exemplify a teaching situation where a grammar topic is taught intuitively?

To provide new insights to the field by adding to similar research in this context, the abovementioned questions were directed at preservice Turkish teachers, and their responses were explained and interpreted comparatively by researchers.

\section{Method}

This is a case study based on qualitative research methods, and a survey research design was implemented. Out of all purposive sampling methods, convenience sampling was used to designate the study group. The participants were 120 preservice Turkish teachers from the Department of Turkish Language Teaching, Dokuz Eylül University; 60 of them were 3rd grade students, while the other half was 4th graders.

For data collection, a semi-structured interview form was designed based on consultation with scholars in the field. A special concern was directed to intelligibility and appropriateness to literature. The gathered data were examined through the content analysis method. Content analysis involves the organizing of data in terms of similar concepts and themes and interpreting them, such that readers can comprehend their significance (Karataş, 2015, p. 71). Thus, the data were categorized based on similarities of responses by tabulating the exemplary opinions obtained from the participants, for interpretation.

\section{Results and Conclusion}

Based on the interview data, a majority of preservice teachers (69\%) believe that intuitive grammar was 
taught to them. However, participants stated that they did not get sufficient information with regard to employing grammar teaching through intuition and felt inadequate in the area. Thus, it was observed that the examples provided by the participants concerning the method were quite limited and insufficient and also similar to one another. These were mostly examples on underlining the function of any noun phrase by extracting it from the entire text. Consequently, based on the data obtained from the study, it was found that participants did not feel ready to teach grammar through intuition.

In conclusion, it is explicit from the findings of the study that the introduction of a lesson on grammar teaching through intuition and being equipped with corresponding practice elements, is essential for preservice teachers. The absence of lessons on teaching grammar while there is an abundance of classes on teaching listening, speaking, reading, and writing is a vital deficiency. Furthermore, the works, research, and materials in the area are not adequate. Thus, these limitations should be rectified. 